\title{
Microhabitat hydraulics predict algae growth in running systems
}

\author{
Ricardo Cardoso-Leite ${ }^{\mathrm{a}}$, Rhainer Guillermo-Ferreira ${ }^{\mathrm{a}, \mathrm{c}}$, \\ Marcos Carneiro Novaes ${ }^{\mathrm{a}}$, Aurélio Fajar Tonetto ${ }^{\mathrm{b}, \mathrm{c}, *}$ \\ ${ }^{a}$ Biology Department, College of Philosophy, Sciences and Letters from Ribeirão Preto, University of São Paulo, Ribeirão Preto, São Paulo, \\ Brazil \\ ${ }^{\mathrm{b}}$ Botany Department, São Paulo State University, Rio Claro, São Paulo, Brazil \\ ${ }^{\mathrm{c}}$ Laboratory of Aquatic Biology, São Paulo State University, Assis, São Paulo, Brazi
}

\section{A R T I C L E I N F O}

\section{Article history:}

Received 16 August 2014

Accepted 18 December 2014

Available online 3 January 2015

\section{Keywords:}

Microalgae

Development

Freshwater

Flume

\begin{abstract}
A B S T R A C T
The properties of surface roughness have been considered an important factor in algal growth. The most relevant finding is that rougher surfaces supports higher algal accumulation. However, the stimulatory effects of roughness have not been tested so far. Thus, here we carried out an experiment using an increasing level of roughness in two different flow conditions. Hence, we investigated the roughness stimulatory threshold for algae growth under different flow conditions, in order to assess the effect of hydraulic dynamics. In the slower flow, the stimulatory threshold did not occurred (high algal coverage in all roughness levels), while in the faster one it could be observed (algal coverage varies among roughness levels). The drag force in slower flow flume was lower than in faster flume. The low values of drag force may have reduced the effects of roughness, which was highlighted in the fast flow flume. Therefore, we suggest that hydraulic dynamics can regulate the roughness stimulatory threshold mechanisms and the peak of algal accumulation is directly dependent of these conditions.
\end{abstract}

(c) 2014 European Regional Centre for Ecohydrology of Polish Academy of Sciences. Published by Elsevier Urban \& Partner Sp. z o.o. All rights reserved.

\section{Introduction}

Hydraulic conditions have been considered as one of the major predictors of flora and fauna settlement and distribution in aquatic environments (Brooks et al., 2005; Biggs et al., 2005; Graba et al., 2013). Hydraulic/hydrologic disturbance may negatively affect the effects of refuges provided by complex habitats for stream communities (Brown, 2007). The relation between hydraulic conditions and features of the surface can determine where the

\footnotetext{
* Corresponding author at: Laboratory of Aquatic Biology, São Paulo State University, Assis, São Paulo, Brazil. Tel.: +55 11983564550.

E-mail address: tonettoaf@gmail.com (A. Fajar Tonetto).
}

organism will most successfully attach (Ditsche-Kuru et al., 2010; Ditsche et al., 2014; Biggs and Hickey, 1994; Tonetto et al., 2014). Therefore, studies focusing on the settlement of aquatic organisms must consider the interaction between hydrodynamics features, such as water velocity, and substrate physical aspects, such as roughness.

The theoretical and empirical framework predicts that freshwater stream algae adhesion is under high pressure and constraints associated with river bed roughness. Stream bottoms are composed of various irregularities such as pits, crevices, moss and other projections (Taniguchi and Tokeshi, 2004). Several studies have shown that higher algal accumulation owes to increased sedimentation efficiency (Johnson, 1994) and protection from 
physical disturbances (Dudley and D'Antonio, 1991; Bergey and Weaver, 2004) provided by rougher substrates. In this context, recent evidence suggests that there is a threshold imposed by surface texture to algae growth and development in rough surfaces. As previously stated, the stimulatory effects of increased texture on algal biomass accrual decrease as roughness increases past a certain point, creating a stimulatory threshold (Murdock and Dodds, 2007).

Nevertheless, the influence of the microhabitat hydrodynamics on the stimulatory threshold of algae settlement has been underexplored. Schneck and Melo (2012) assessed the effects of hydrological disturbance on algal accumulation, but only in two types of surface roughness (smooth vs. rough). Here, our objective was to investigate the surface features in a gradient of roughness in an attempt to find the stimulatory limit for algae accumulation, regarding the interaction between hydraulics and roughness. Hence, we measured hydraulic parameters associated to individual surfaces in order to assess the role of substrate texture properties in algae colonization on various rough surfaces. Indeed, the relationship between the microhabitat hydrodynamics and the accumulation of algal assemblages has been seldom explored. Following Resh et al. (1988), we consider that disturbance of water flow is a dominant organizing factor in stream ecology. Therefore, we hypothesized that increasing disturbance by water flow would change the roughness effect on algae accumulation.

\section{Materials and methods}

We built two separate flumes ( $5 \mathrm{~m}$ length $\times 0.15 \mathrm{~m}$ width) with different inclination angles to create two different water flow conditions. Water velocity was measured with a Swoffer 3000 flowmeter. The faster flume recorded a mean velocity of $1.33 \pm 0.05 \mathrm{~m} / \mathrm{s}$, while a mean velocity of $0.81 \pm 0.1 \mathrm{~m} / \mathrm{s}$ in the slower flume. A set of four levels of rougher surfaces (i.e. sand paper of four grain sizes), in an increasing gradient, were fixed at the bottom of both flumes. Thus, we were able to assess the effect of roughness in two different flow conditions.

The rough surfaces were four kinds of sandpaper stripes, measuring $75 \times 25 \mathrm{~mm}$ (similar to microscopic slides dimensions) and were set up in random positions along the flumes. These sandpaper stripes have known roughness indices $(80,120,220$ and 320 grit), where these values represent the number of sand grains in $1 \mathrm{~cm}^{2}$. Ten replicates of each kind of sandpaper were used on each flume, totalizing 80 sandpaper stripes. Algae were collected at natural streams in Assis, São Paulo, Brazil $\left(22^{\circ} 38^{\prime} \mathrm{S}, 50^{\circ} 27^{\prime} \mathrm{W}\right.$; altitude $\left.522 \mathrm{~m}\right)$ and inserted in the system by dropping the water with algae in the water reservoir. Thus, algae were pumped through the system and had equal chances to settle in any part of the flume.

We calculated the drag force for the four roughness levels in each flume. We assumed that drag force was a good predictor of the roughness threshold. Drag force was used to represent the resistance to flow caused by the object (i.e. sandpaper stripes). This force can be related to the permanence of organisms under the object or attached to the surface (Gordon et al., 2004). Drag force is defined in Eq. (1):

$F_{s}=C_{f} W L \rho \frac{V^{2}}{2}$

where $C_{f}$ is the skin friction coefficient which depends of the flow type and is calculated using $L$ and height of the pits and crevices; $W$ and $L$ are width and length of the surface pieces $(\mathrm{m})$ and $\rho$ is the fluid density $\left(\mathrm{kg} / \mathrm{m}^{3}\right)$. Table 1 shows the drag force variation among roughness level and between flumes. The experiment consisted of four different roughness groups under two different water velocities, hence, a total number of eight treatment groups with different drag forces. The coverage of algae was recorded 10 days after the installation of all surfaces. This period is considered suitable for algal settlement (Danger et al., 2013). The surface area coverage (SAC-\%) of the biofilm in the pictures was calculated in a standardized centered area $\left(1 \mathrm{~cm}^{2}\right)$, to avoid border effects, using Adobe Photoshop (Tonetto et al., 2012). This technique was adapted from $\mathrm{Ng}$ et al. (2014), Singer et al. (2006) and recent studies have used percent coverage as an algal metric (Tonetto et al., 2012, 2014).

Differences in algae growth in relation to drag force were analyzed with ANOVA tests. The influence of velocity in algae SAC was analyzed with logistic regression tests, using water flow as a dichotomist variable (i.e. slow vs. fast) and covered area as a continuous variable to assess the probability of algae to settle in slow or fast streams. All statistical analyses were made using the software Statistica 10

\section{Results}

The algal community was mainly composed by specimens of the genera Coelastrum, Chlamydomonas, Desmodesmus, Staurastrum and few individuals of diatoms (basically the genera Eunotia, Navicula and Gomphonema). Table 1 showed that drag force was lower in the slow flow flume. In slow waters algae are able to attach more easily to the substrates and to stay attached, and thus they can exhibit higher accumulation. Indeed, the results from logistic regression indicate that algae showed more accumulation in the slow velocity flume, and thus a preference for this condition (logistic regression: $X^{2}=31.95, p<0.00001$, Fig. 1). There was a relationship

Table 1

Treatment groups regarding roughness of the sandpapers and drag force acting in each group. The numbers $1-4$ indicate the polishing paper in the slow water flume and 5-8 indicate the same roughness variation, but in the fast flow flume.

\begin{tabular}{lll}
\hline $\begin{array}{l}\text { Treatment } \\
\text { group }\end{array}$ & $\begin{array}{l}\text { Roughness } \\
(\mathrm{m})\end{array}$ & $\begin{array}{l}\text { Drag force } \\
\text { (Newton) }\end{array}$ \\
\hline 1 & 0.000284 & $1.71 \mathrm{E}-05$ \\
2 & 0.000232 & $1.73 \mathrm{E}-05$ \\
3 & 0.000171 & $1.78 \mathrm{E}-05$ \\
4 & 0.000142 & $1.8 \mathrm{E}-05$ \\
5 & 0.000284 & $3.03 \mathrm{E}-05$ \\
6 & 0.000232 & $3.08 \mathrm{E}-05$ \\
7 & 0.000171 & $3.16 \mathrm{E}-05$ \\
8 & 0.000142 & $3.2 \mathrm{E}-05$ \\
\hline
\end{tabular}




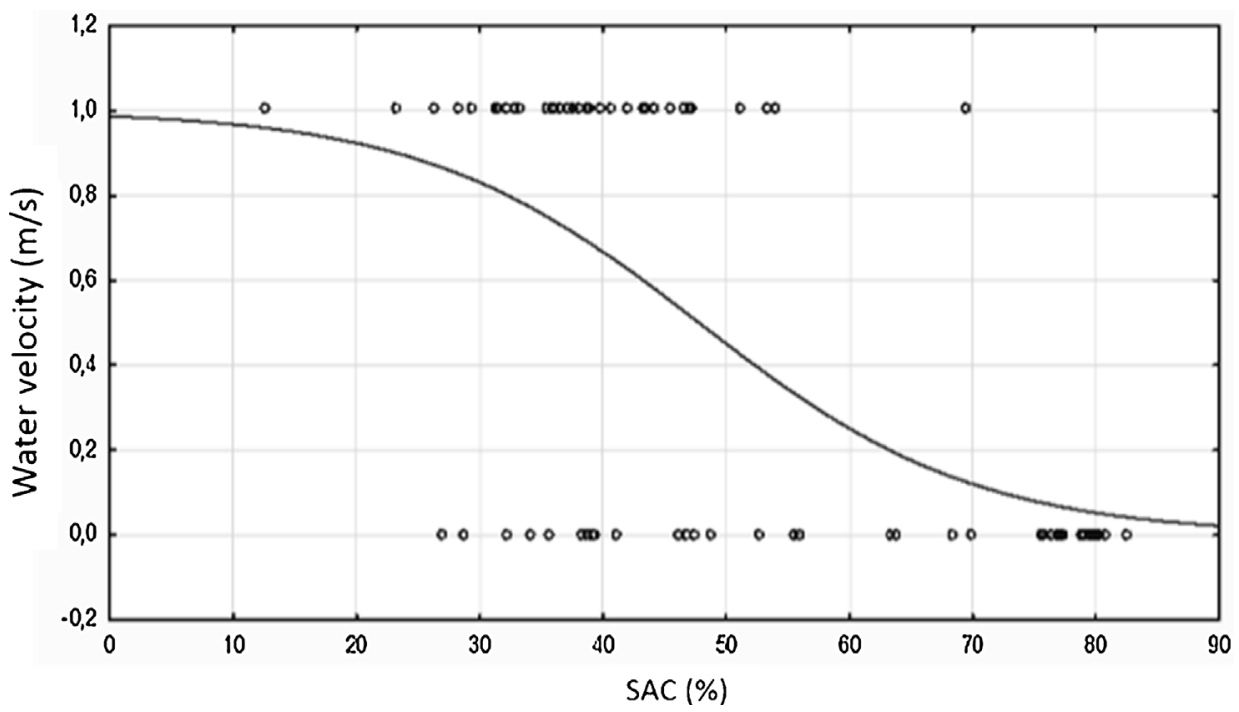

Fig. 1. Estimated probability of algae growth according to stream velocity ( $0=$ slow; $1=$ fast $)$ as a function of algae biomass in 80 different substrates with different roughness. The logistic regression indicates that algae exhibit higher probabilities of settling in slow water flow streams. SAC means surface area coverage in percentage.

between SAC and drag force (ANOVA, $p=0.000003$, Fig. 2). In the slow water flow flume, there was no difference in algae SAC in relation to drag force (ANOVA, $p=0.59$, Fig. 2), but the analyses showed differences in the faster water flow flume (ANOVA, $p=0.03$, Fig. 2).

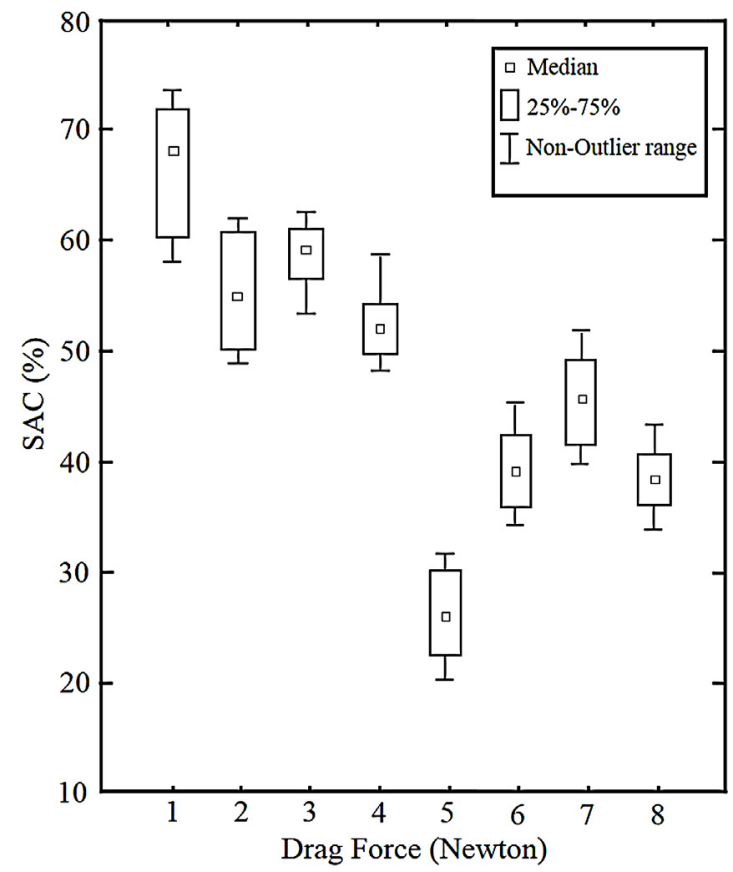

Fig. 2. The relationship between percentages of area covered by algae and drag force. (1-4) Slow flow flume. (5-8) Fast flow flume. The numbers 1-4 indicate the polishing paper in the slow water flume and 5-8 indicate the same roughness variation, but in the fast flow flume.

\section{Discussion}

The variation in the hydraulic conditions showed an important role in algal accumulation. The slower flume with lower drag forces recorded higher percent coverage of algae independently of roughness level. Similar to Graba et al. (2013), the highest drag forces slowed down the deposition and attachment of algal cells in the higher flow regime, preventing higher accumulations in all surfaces. Nevertheless, the roughness stimulatory threshold is visible in the fast flow flume, since algal SAC increase until intermediate roughness. Hence, these results corroborate our initial hypothesis, indicating that hydraulic dynamics can modulate the stimulatory threshold mechanisms which regulate when algae will achieve its maximum growth.

In this context, the response of algal accumulation showed that stimulatory threshold varied between slower and faster flumes. The former showed no differences in algal accumulation among roughness levels, which reveal no stimulatory effect of increasing roughness. Actually, the roughness differences among surfaces were not relevant for algal growth in slower flow. The reason is probably related to lower drag forces in this flume, which can favor algal colonization (Tonetto et al., 2014) by benefiting cell migration and development. It is well known that cell migration is the dominant mechanism of algal accumulation during early stages of community development, when algal densities are very low (Stevenson et al., 1996). Furthermore, a higher sedimentation of detritus within crevices in slower flumes may have contributed to our results due to the higher amounts of nutritional resources for algal development in any roughness level in these hydraulic conditions.

In turn, the higher values of drag force in the faster flume allow the action of the stimulatory threshold effects of roughness on algal accumulation. As we predicted, when fast water flow conditions constraints algal growth, cell 
attachment was influenced by substrate roughness. Indeed, our results show that in the faster flume algal growth was stimulated up to the third level of roughness following by a reduction after that. In this scenario, there is a maximum roughness threshold, beyond which there will be lower algal accumulation. Briefly, the reasons for a rougher surface exhibit higher algal accumulation are increased sedimentation efficiency and cell adhesion, protection from disturbances, such as scour or grazing, and alteration of flow around the substrate (Murdock and Dodds, 2007). However, the authors Bergey and Weaver (2004) showed that by increasing the size of crevices, they no longer act as refuges. In our study, in the faster flow flume, the higher drag forces showed this relation, indeed. In addition, larger surface areas found in rougher surfaces create lower quality attachment sites (Robson and Barmuta, 1998).

\section{Conclusions}

We demonstrate that algal accumulation is dependent of a stimulatory effect of roughness, which is constrained by flow conditions. When drag force is sufficiently strong to dislodge algae, the roughness variation will be important for algae development on flowing habitats. We finally suggest that the physical properties of texture can provide heterogeneous hydraulic microhabitats, which may lead to different colonization dynamics and constraint the roughness stimulatory mechanisms.

\section{Conflict of interest}

None declared.

\section{Financial disclosure}

None declared.

\section{Acknowledgments}

The authors would like to thank FAPESP (proc. 2010/ 17563-0, proc. 2013/00406-7), CNPq and CAPES for financial support.

\section{References}

Bergey, E.A., Weaver, J., 2004. The influence of crevice size on the protection of epilithic algae from grazers. Freshw. Biol. 49, 1014-1025.
Biggs, B.J., Hickey, C.W., 1994. Periphyton responses to a hydraulic gradient in a regulated river in New Zealand. Freshw. Biol. 32 (1), 49-59.

Biggs, B.J., Nikora, V.I., Snelder, T.H., 2005. Linking scales of flow variability to lotic ecosystem structure and function. River Res. Appl. 21 (2-3), 283-298

Brooks, A.J., Haeusler, T., Reinfelds, I., Williams, S., 2005. Hydraulic microhabitat and the distribution of macroinvertebrate assemblages in riffles. Freshw. Biol. 50, 331-344.

Brown, B.L., 2007. Habitat heterogeneity and disturbance influence patterns of community temporal variability in a small temperate stream. Hydrobiologia 586, 93-106.

Danger, M., Cornut, J., Chauvet, E., Chavez, P., Elger, A., Lecerf, A., 2013. Benthic algae stimulate leaf litter decomposition in detritus-based headwater streams: a case of aquatic priming effect? Ecology 94, 1604-1613.

Ditsche, P., Michels, J., Kovalev, A., Koop, J., Gorb, S., 2014. More than just slippery: the impact of biofilm on the attachment of non-sessile freshwater mayfly larvae. J. R. Soc. Interface 11 (92), 1742-5662.

Ditsche-Kuru, P., Koop, J.H.E., Gorb, S.N., 2010. Underwater attachment in current: the role of setose attachment structures on the gills of the mayfly larvae Epeorus assimilis (Ephemeroptera, Heptageniidae). J. Exp. Biol. 213 (11), 1950-1959.

Dudley, T.L., D'Antonio, C.M., 1991. The effects of surface texture, grazing, and disturbance on macroalgal establishment in streams. Ecology 72 297-304.

Gordon, N.D., McMahon, T.A., Finlayson, B.L., Gippel, C.J., Nathan, R.J., 2004. Stream Hydrology: An Introduction for Ecologists, 2nd ed. John Wiley and Sons, West Sessex, UK.

Graba, M., Sauvage, S., Moulind, F.Y., Urreaf, G., Sabaterf, S., SanchezPerez, J.M., 2013. Interaction between local hydrodynamics and algal community in epilithic biofilm. Water Res. 47, 2153-2163.

Johnson, L.E., 1994. Enhanced settlement on microtopographical high points by the intertidal red alga Hallosaccion glandiforme. Limnol Oceanogr. 39, 1893-1902.

Murdock, J.N., Dodds, W.K., 2007. Linking benthic algal biomass to stream substratum topography. J. Phycol. 43, 449-460.

Ng, F.L., Phang, S.M., Periasamy, V., Yunus, K., Fisher, A.C., 2014. Evaluation of algal biofilms on indium tin oxide (ITO) for use in biophotovoltaic platforms based on photosynthetic performance. PLOS ONE 9 (5), e97643.

Resh, V.H., Brown, A.V., Covich, A.P., Gurtz, M.E., Li, H.W., Minshall, G.W. Reice, S.R., Sheldon, A.L., Wallace, J.B., Wissmar, R., 1988. The role of disturbance in stream ecology. J. N. Am. Benthol. Soc. 7, 433-455.

Robson, B.J., Barmuta, L.A., 1998. The effect of two scales of habitat architecture on benthic grazing in a river. Freshw. Biol. 39, 207-220.

Schneck, F., Melo, A.S., 2012. Hydrological disturbance overrides the effect of substratum roughness on the resistance and resilience of stream benthic algae. Freshw. Biol. 57 (8), 1678-1688.

Singer, G., Besemer, K., Hödl, I., Chlup, A.K., Hochedlinger, G., Stadler, P., Battin, T.J., 2006. Microcosm design and evaluation to study stream microbial biofilms. Limnol. Oceanogr. 4, 436-447.

Stevenson, R.J., Bothwell, M.L., Lowe, R.L., 1996. Algal Ecology - Freshwater Benthic Ecosystems. Academic Press, San Diego.

Taniguchi, H., Tokeshi, M., 2004. Effects of habitat complexity on benthic assemblages in a variable environment. Freshw. Biol. 49, 1164-1178.

Tonetto, A.F., Cardoso-Leite, R., Peres, C.K., Bispo, P.C., Branco, C.C.Z., 2014. The effects of habitat complexity and hydraulic conditions on the establishment of benthic stream macroalgae. Freshw. Biol. 59 (8), 1687-1694.

Tonetto, A.F., Peres, C.K., Branco, C.C.Z., 2012. A new method to quantify macroalgae and a practical sampler for experimentation in lotic habitats. Braz. J. Biol. 72 (4), 1-5. 